\title{
The comparison of fulvic acids extracted from the primary and secondary effluent
}

\author{
Dominika Łomińska-Płatek ${ }^{1, *}$, and Anna M. Anielak ${ }^{1}$ \\ ${ }^{1}$ Department of Environmental Engineering, Institute of Water Supply and Environmental Protection, \\ Cracow University of Technology, 24 Warszawska, 31-155 Cracow, Poland
}

\begin{abstract}
As is well known without organic matter, there would be no life. Organic compounds perform very important functions in the whole ecosystem as: structural, storage, transport, catalyse reactions, immune and regulatory functions. One of the most important for both living and nonliving organic matter is their role in the biogeochemical cycles of carbon, phosphorus, nitrogen and others elements. The major form of organic matter are humic substances (HS) which are a mixture of high molecular weight organic compounds with variable composition. Humic substances can be divided into: humic acids (HA), fulvic acids (FA) and humins (Hu). In the presented research FA were studied. They were extracted from the effluent in the process of ion exchange in a hydrophobic ion exchanger and then they were examined by qualitative analysis to determine the elemental composition of acids and the degree of contamination with heavy metals and other substances. The main aim was to balance and assess the amount of FA in the primary and secondary effluent. The studies have shown that concentration of FA in raw wastewater (primary effluent) was bigger than in the treated wastewater (secondary effluent). Based on the research, it can be stated that selected WWTP discharges less FA compared to the input pollution load.
\end{abstract}

\section{Introduction}

Humic substances (HS) are formed by humification of animal and plant remains substances, such as lignin, proteins, pectins, polysaccharides, and others. They are the most widely spread natural complexing ligands occurring in nature [1]. HS are commonly present in groundwater, surface water and soils. HS are macromolecular compounds with a very complex and heterogeneous structure [2]. In natural conditions, these substances are differentiated in terms of construction which results from the different degrees of decay. HS are usually a mixture of organic compounds of an acidic nature and closer to the unknown structure. These substances have been known for hundred years, but their structural composition has not yet been recognized. There are many models that only approximate their construction. The elemental composition of fulvic acids (FA) and humic acids (HA) consists of carbon, hydrogen, oxygen, nitrogen and sulphur. It is considered that FA contains about $14.5 \%$ more oxygen than $\mathrm{HA}$, about $5 \%$ less carbon and approximate values

\footnotetext{
* Corresponding author: dominika.lominska@pk.edu.pl
} 
of nitrogen and sulphur. Researches [3-5] confirm that the elemental compositions of different FA and HA have the following major elements in their structure: $\mathrm{C}, \mathrm{H}, \mathrm{N}, \mathrm{O}$ and $\mathrm{S}$ and this is always present regardless of their origin, country or continent. Major functional groups of HS are: carboxylic, phenolic, carbonyl, hydroxyl, amine, amide and aromatic moieties, among others [1]. Generally, the discussed substances can be divided into: HA, which are soluble in alkaline solution, precipitating in the hydrochloric acid solution; FA soluble in water, acidic solutions (even at $\mathrm{pH}$ of about 1 and alkaline solutions and humins which are insoluble in acidic or alkaline solutions. Kononova further distinguishes hymatomelanic acids, soluble in alcohol [6]. Some authors consider that wastewater treatment plants can be a source of humic acids in surface waters. According to Pempkowiak the amount of humic substances in the treated wastewater may depend on the size of the treatment plant, the composition of raw wastewater and technology [7].

\section{Humic substances in water and wastewater}

The coexistence of HS and iron in groundwater causes that a specified part of iron occurs in the form of iron-organic bound. As a result, water has an increased colour and turbidity, which is problematic, in the technological aspect, for efficient treatment. This is practically impossible to achieve in conventional groundwater treatment processes [6]. Generally, surface waters are dominated by FA, their content is in the range $1-100 \mathrm{mg} / \mathrm{L}$ [8]. FA also dominate in groundwater. FA have an ability to bind metal ions and then determine the fate of heavy metals in the environment [9]. Despite the fact that HS are nontoxic compounds, they have a significant influence on selection, design and operation of the water treatment process [10-12]. It is worth noting that molecular weight of HA and FA in drinking water is in the range from $10^{3}$ to $10^{6}[13]$. Because of the fact that FA are soluble throughout the $\mathrm{pH}$ scale, they can be the most dangerous among all humic acids. FA are precursors of carcinogenic and mutagenic compounds produced during oxidation and disinfection processes. FA include substances, such as trihalomethanes (THM), haloacetic acids (HAA), halogeno-nitriles, halogeno ketones, trichlorophenol, trichlorobenzenes, hydroxi-furanes and others [14]. According to authors [7] one of the sources of HS are municipal wastewater treatment plants [7]. Researchers proved that a significant part of organic substances contained in wastewater after hydrophyte treatment plants has properties similar to humic acids properties [7]. Generally the presence of HS in natural water has an influence on such factors as water colour, deterioration of the taste and odour of water, precursors of halogenoorganic compounds (DBPs), harmful interactions with heavy metals, other harmful organic compounds, micro-contaminants and their effect on their transport in the aquatic environment. Because of the mentioned factors and high content of FA, it can be conducted that fulvic acids may have a negative influence on surface water.

Despite these facts, HS play an important role in the whole environment. As a major part of natural organic matter (NOM), they can be removed from drinking water in coagulation and flocculation (these two methods are most common and economical) followed by decantation and sand filtration $[10,15]$. Based on the above examples, it can be concluded that the HS play a negative (mainly in surface and underground water) as well as positive (for soil) role in the environment. 


\section{Methodology of research}

The samples were collected directly from the primary and secondary effluent at the wastewater treatment plant. The selected wastewater treatment plant treats mainly wastewater from industrial plants and individual users. The WWTP comprises mechanical and biological wastewater trains, sludge processing and biogas trains. The plant works as a three stage Bardenpho system and operates five identical biological reactors. The wastewater treatment process comprises the following unit processes: pre-denitrification, biological phosphorus removal, nitrification and denitrification. The average wastewater flow is 165 thousand $\mathrm{m}^{3} /$ day while a capacity of a biological stage is 320 thousand $\mathrm{m}^{3} /$ day (Information acquired from the WWTP). The wastewater sample had a volume of $50 \mathrm{~L}$ (primary effluent) and $339 \mathrm{~L}$ (secondary effluent). Both primary and secondary samples were collected several times and the given results are averaged. FA were extracted from the collected material in a laboratory. FA were isolated from the collected samples in accordance with the procedure [16, 17]. The concentration of the FA solution was determined in a vacuum evaporator and was specified by the determination of dry residue. The results of the elemental composition were converted to ashless mass. A study of the elemental composition provided information regarding the structure of isolated acids, the origin of their organic matter as well as the degree of aromatization and condensation. The analysis of the elemental composition was commissioned to a unit equipped with the required analytical apparatus. A basic principle of this analysis is to obtain the high temperature at which the oxidizing combustion of samples takes place. The gaseous products of combustion are treated, separated in adsorption columns into individual components, and then detected in the measuring cell of a thermal conductivity detector. The content of elementary elements will be quoted on an ash-free material basis. The ash content of FA will be determined independently by combusting the sample at $550^{\circ} \mathrm{C}$ for 30 minutes. Trace metals contained in FA were designated by cuvette atomic absorption spectrometry. The analysis was performed at the certified laboratory.

\section{Results}

The concentration of FA in the primary effluent was $14.8 \mathrm{~g} / \mathrm{m}^{3}$, while the secondary effluent had a concentration of $5.2 \mathrm{~g} / \mathrm{m}^{3}$; both samples had a brown colour. They were contaminated with inorganic substances $(\mathrm{Cl}, \mathrm{Si}, \mathrm{Na}, \mathrm{Ca}, \mathrm{K}, \mathrm{P}, \mathrm{Mg}$, and $\mathrm{Fe}, \mathrm{Br})$. The ash content based on weight percent of the primary effluent was $11.55 \%$, and of the secondary effluent, it was $9.74 \%$, which indicated a large number of inorganic impurities, higher in the primary effluent. Additionally, compared the ash content from selected WWTP with data from two different WWTPs in Poland (Jamno and Unieście) and WWTP in USA (Wilmington). The biggest ash content is for the last one $42.27 \%$ and this is almost four times more than from tested WWTP, this indicate very high content of inorganic substances. For the WWTPs in Poland it was accordingly $24 \%$ and $23 \%$. 
Table 1. Comparison of the properties of FA extracted from the different WWTPs.

\begin{tabular}{|c|c|c|c|}
\hline \multirow{2}{*}{ Samples } & Fulvic acids & Ash & \multirow{2}{*}{ Literature } \\
\cline { 2 - 4 } & {$\left[\mathrm{g} / \mathrm{m}^{3}\right]$} & {$[\%]$} & {$[18]$} \\
\hline Primary effluent Płaszów WWTP & 14.8 & 11.55 & {$[19]$} \\
\hline Secondary effluent Płaszów WWTP & 5.2 & 9.74 & {$[7]$} \\
\hline Jamno WWTP & 2.8 & 24 & {$[7]$} \\
\hline Unieście WWTP & 3.2 & 23 & {$[20]$} \\
\hline Wilmington WWTP & - & 42.27 & \\
\hline
\end{tabular}

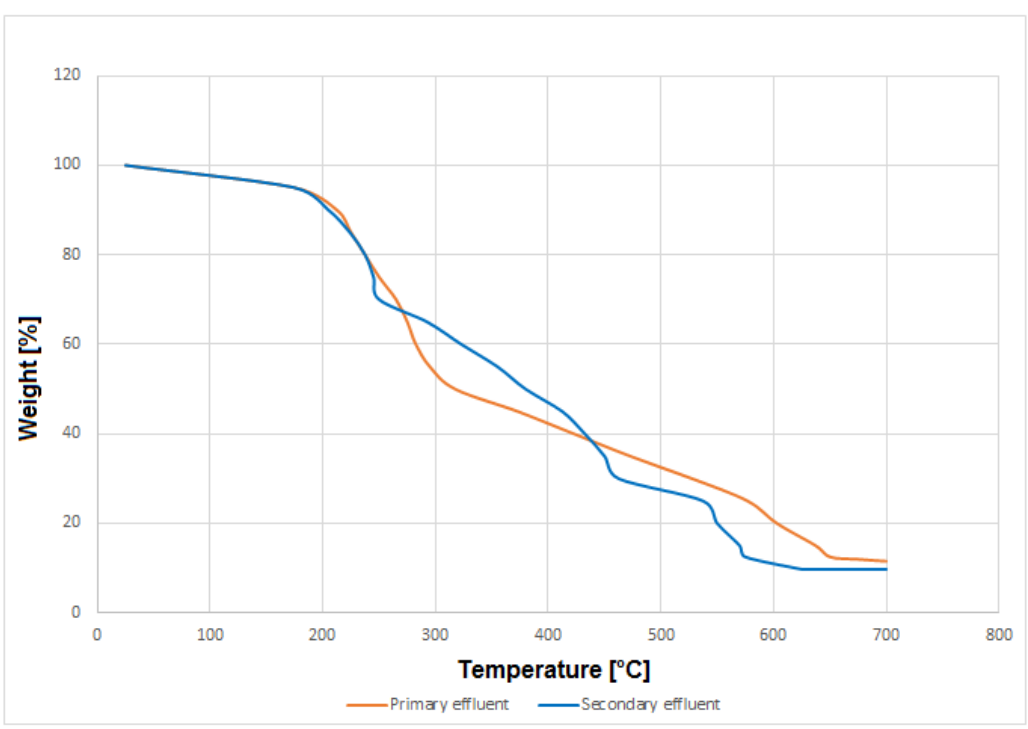

Fig. 1. Mass reduction in wastewater samples after primary and secondary treatment as a function of temperature (Author's work on the basis on $[18,19]$ ).

By analysing Figure 1, it can be seen that, for $100^{\circ} \mathrm{C}$ and $200^{\circ} \mathrm{C}$ the mass reduction is similar for both extracted FA. Small differences in the temperature range of $250-430^{\circ} \mathrm{C}$ between the curves may be the result of FA containing more oxygen in the primary effluent which probably evaporates into the atmosphere in the given temperature range. At higher temperatures, overcoming disparities can be the result of the higher carbon content of FA contained in the secondary effluent. At an ash content of $11.55 \%$ and $9.74 \%$, the weight of samples remained unchanged, despite the fact that temperature rose up to $700^{\circ} \mathrm{C}$. The mass remained constant at a temperature of approx. $580^{\circ} \mathrm{C}$, which was slightly higher than the temperature specified in the applicable standards $\left(550^{\circ} \mathrm{C}\right)$. It can be shown that volatile substances are similar to both primary and secondary effluents. 


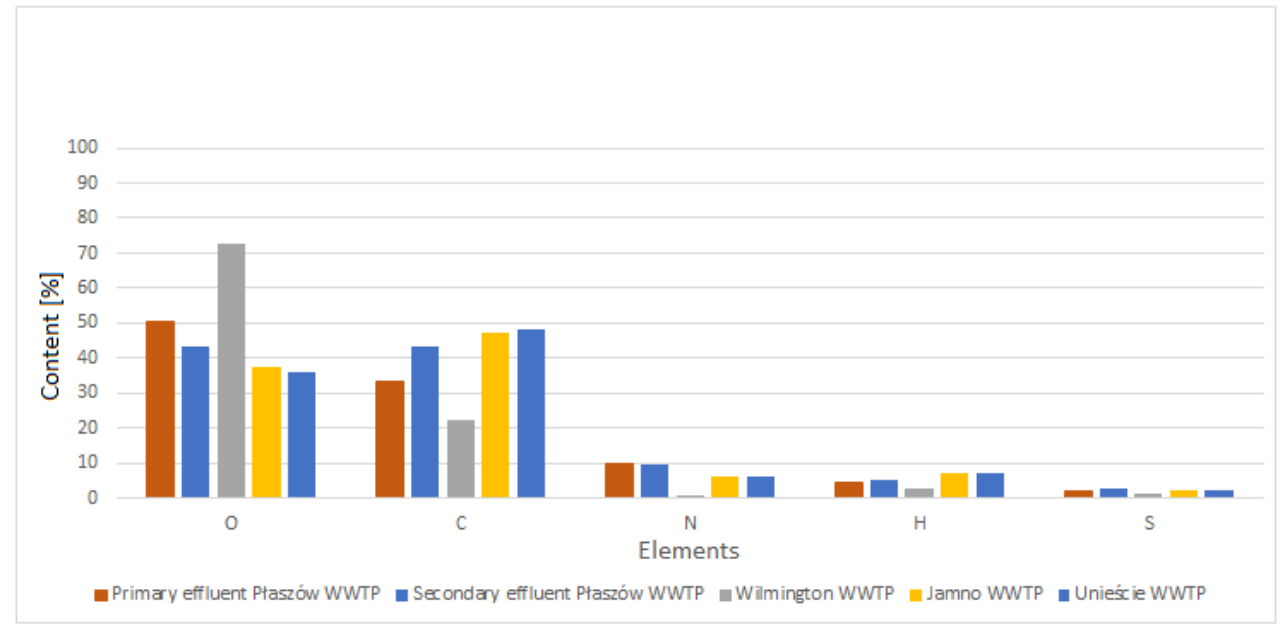

Fig. 2. Elemental composition of FA extracted from different WWTPs (Author's work on the basis on $[7,18-20])$.

Comparing the values with the results for the primary and secondary effluent, it may be noticed that there are some differences in the elemental composition of FA extracted from a different location of WWTP. The main components of FA extracted from the primary and the secondary effluent are: oxygen, content of which in ash-free mass in primary effluent is $50.26 \%$ and it is higher than for the secondary effluent, which is $38.98 \%$; carbon in an amount of $33.24 \%$ (primary effluent) and $43.51 \%$ (secondary effluent). Oxygen was determined directly via mass balance $(100 \%-\mathrm{C}-\mathrm{H}-\mathrm{N}-\mathrm{S})$. According to, [21] a high oxygen content in the structure of FA may indicate the presence of carboxyl, carbonyl, methoxy, hydroxyl, alcohol, ester and steering groups. According to Figure 2, hydrogen content is $4.60 \%$ (primary effluent) and $5.37 \%$ (secondary effluent), so in the second sample, there was more hydrogen. Sulphur content is $1.87 \%$ (primary effluent) and $2.7 \%$ (secondary effluent); nitrogen content is higher in the primary effluent at $10.03 \%$, while in the secondary effluent it is $9.44 \%$. The high content of nitrogen may indicate the presence of amino acids in their structure. Comparing all samples, the value for Płaszów, Unieście and Jamno WWTPs are similar, but for the Wilmington WWTP it can be noticed that FA contains much more oxygen than $70 \%$ and less other elements $(\mathrm{C}, \mathrm{H}, \mathrm{N}$ and $\mathrm{S}$ ).

The degree of oxidation of the extracted FA molecule was determined by the value of $\omega$ on the basis on Żdanow formula:

$$
\omega=[(2 O+3 N)-H] / C
$$

where: $O, N, H$ and $C$ - content of $\mathrm{O}, \mathrm{N}, \mathrm{H}$ and $\mathrm{C}$ expressed as atomic percent.

The degree of inside oxidation of particles for the primary effluent is 3.8 and for the secondary effluent is 2.3. According to authors [22, 23], $\omega$ is an objective parameter of oxidation, which considers all the elemental composition, so in this case values for both primary and secondary effluent indicate a high degree of oxidation, which confirms the high level of humifiaction [22, 23]. 
Table 2. Atomic ratios in FA extracted from the different WWTPs.

\begin{tabular}{|c|c|c|c|c|}
\hline \multirow{2}{*}{ Samples } & \multicolumn{3}{|c|}{ Atomic ratios } & \multirow{2}{*}{ Literature } \\
\cline { 2 - 5 } & $\mathrm{C} / \mathrm{O}$ & $\mathrm{C} / \mathrm{H}$ & $\mathrm{C} / \mathrm{N}$ & \\
\hline Primary effluent Płaszów WWTP & 0.52 & 7.22 & 3.31 & {$[18]$} \\
\hline Secondary effluent Płaszów WWTP & 1.11 & 8.1 & 4.61 & {$[19]$} \\
\hline Jamno WWTP & 1.26 & 6.61 & 7.62 & {$[7]$} \\
\hline Unieście WWTP & 1.33 & 6.62 & 8.03 & {$[7]$} \\
\hline Wilmington WWTP* & 0.31 & 8.49 & 20.72 & {$[20]$} \\
\hline
\end{tabular}

$*$ in original research [20] because of high ash contents molar ratios were not calculated for these samples.

The $\mathrm{C} / \mathrm{O}$ ratio provides information on acid hydrophobicity. The more carbon, the greater the ratio and the hydrophobicity of acids. According to Table 2, the $\mathrm{C} / \mathrm{O}$ ratio for the FA from the wastewater was 0.52 in the primary effluent and 1.11 in the secondary effluent, so it can be concluded that the acids extracted from the primary effluent were more hydrophilic and had many functional groups. For all samples this ratio is quite small. The $\mathrm{C} / \mathrm{N}$ ratio is relatively small and equals 3.31 (primary effluent), 4.61 (secondary effluent) due to a high nitrogen content in FA (10.03\% for primary and 9.44 for secondary effluent). It can be noticed that for the Wilmington WWTP this ratio is the biggest and it is 20.72. Another issue is the $\mathrm{C} / \mathrm{H}$ ratio, which served as an indicator of aromatization and condensation of $\mathrm{HA}$. The $\mathrm{C} / \mathrm{H}$ ratio for all samples is similar and relatively large. It indicates a substantial degree of aromatization.

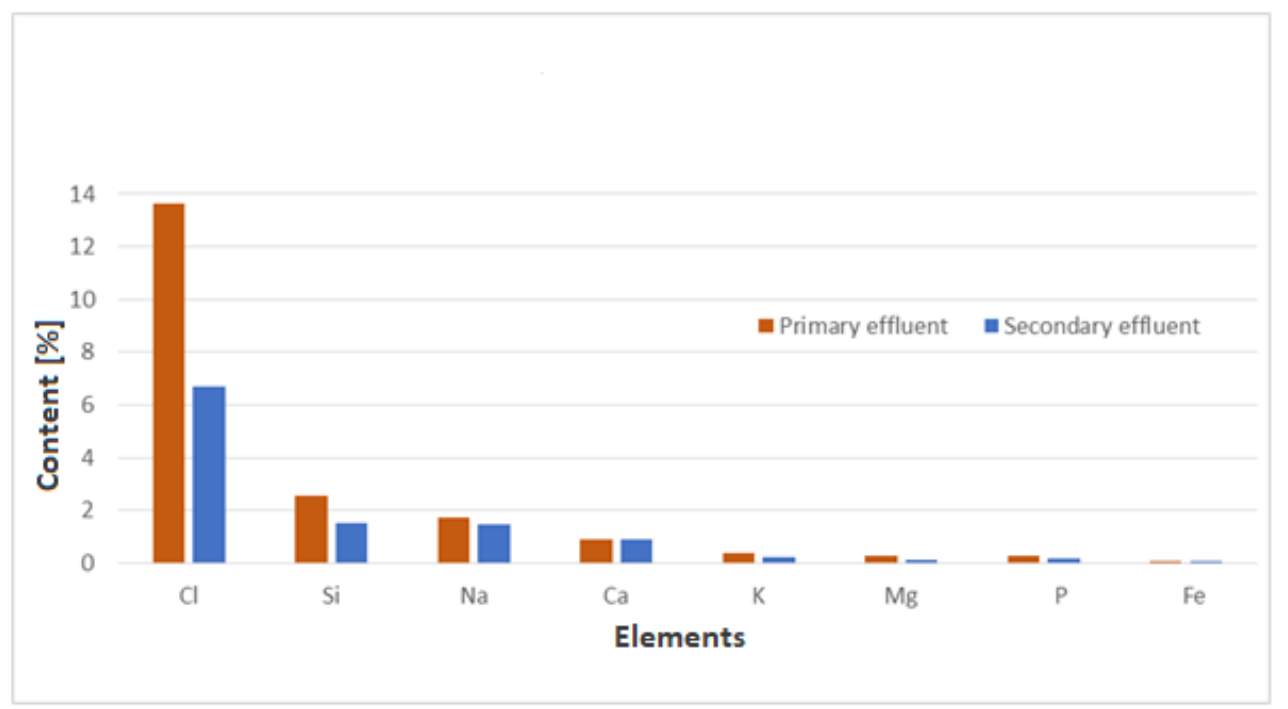

Fig. 3. Trace elements content in fulvic acids extracted from the primary and secondary effluent from the Płaszów WWTP (Author's work on the basis on $[18,19]$ ).

By comparing the primary and secondary effluent values of trace elements in FA, it can be noticed that the first sample has a much higher content of trace elements in its construction. The trace element with the largest content in FA extracted from the wastewater for both primary and secondary effluent was chlorine $13.62 \%$ (primary effluent), $6.68 \%$ (secondary effluent); next was silica $2.58 \%$ (primary effluent), $1.55 \%$ (secondary effluent); and then sodium $1.74 \%$ (primary effluent), $1.45 \%$ (secondary effluent). 


\section{Conclusions}

The main aim of the study was to compare and assess the amount of FA discharged from a wastewater treatment plant in comparison to the input pollution load. FA are a mixture of compounds with a wide molecular weight range, similar elemental composition and ash content independently from the place of collection and type of wastewater (primary and secondary effluent). FA extracted from different WWTPs (Płaszów, Jamno, Unieście and Wilmington) has a similar concentration, elemental composition and ash content, only slightly deviates were noticed in the Wilmington WWTP. The values of the degree of inside oxidation of particles are close to each other. The concentration of FA from the primary effluent was $14.8 \mathrm{~g} / \mathrm{m}^{3}$ and it was higher than from the secondary effluent, which was $5.2 \mathrm{~g} / \mathrm{m}^{3}$. Based on the research, it can be stated that the selected WWTP discharges fewer amounts of FA compared to the input pollution load. FA extracted from the primary effluent contain much more inorganic pollutants than FA from the secondary effluent, while the content of carbon in the FA from the secondary effluent is bigger than in the FA from the primary effluent. These dependencies are the result of physicochemical processes occurring in the biological reactor. Studies have shown that wastewater contains significant amounts of FA which, by penetrating into surface waters, may be precursors of by-products of oxidation and disinfection used in Water Treatment Stations. Therefore, the problem of discharging FA with treated wastewater is important, due to the amount of treated sewage and the place of their discharge (to surface waters).

The presented research results, were realized within the subject number: Ś-3/360/2016/DS-M and have been granted by Ministry of Science and Higher Education.

\section{References}

1. E.M., Peña-Méndez, J. Havel, J. Patočka, Humic Journal of Applied Biomedicine 3, 13-24, (2005)

2. E. Casassas, L. Marqués, R. Tauler, Analytica Chimica Acta 310, 473-484 (1995)

3. D. Gajdošová, L. Pokorná., S. Láska, P. Prošek, J. Havel, Royal Society of Chemistry, 121-131 (2001)

4. K.H. Tan, Chemical composition of humic matter. Humic Matter in Soil and the Environment. Principles and Controversies (Marcel and Dekker, New York, 2003)

5. M. Kurková, Z. Klika, Ch. Kliková, J. Havel Chemosphere 54, 1237-1245 (2004)

6. I. Krupińska, Inżynieria Środowiska 148, 28 (2012)

7. J. Pempkowiak, H. Obarska-Pempkowiak, M. Gajewska, D. Ruta, Przem. Chem. 87, 5, 542-54 (2008)

8. V. Osadchyy, B. Nabyvantes, P. Linnik, N. Osadcha, Y. Nabyvantes, Processes Determining Surface Water Chemistry, 104 (2016)

9. E. Baidoo, J. Ephraim, G. Darko, O. Akoto, Geoderma 217-218, 18-25 (2014)

10. C. Trellu, Y. Péchaud, N. Oturan, E. Mousset, D. Hugeuenot, E. Hullebusch, G. Esposito, M. Oturan, Applied Catalysis B: Environment 194, 32-41 (2016)

11. G. Hua, D.A. Reckhow, Environ. Sci. Technol. 41, 3309-3315 (2007)

12. V.K. Sharma, R. Zboril, T.J. McDonald, J. Environ. Sci. Health Part B 49, 3, 212-28 (2014) 
13. H.K. Shon, S. Vigneswaran, J. Kandasamy, J. Cho, Water and Wastewater Treatment Technologies, 1 (2007)

14. R. Świderska, A.M. Anielak, Rocznik Ochrona Środowiska 6, 1-49 (2004)

15. A. Matilainen, M. Vepsalainen, M. Sillanpaa, Adv. Colloid Interface Sci. 159, 189-197 (2010)

16. G.R. Aiken, E.M. Thurman, R.L. Malcolm, H.F. Walton, Anal. Chim. Acta 51, 1799-1803 (1979)

17. A.M. Anielak, M. Polus, D. Łomińska, T. Żaba, Przemysł Chemiczny 95, 1, 110-113 (2016)

18. D. Łomińska, A. Anielak, ES3 Web of Conferences 17, 00054 (2017)

19. A.M. Anielak, M. Kryłów, D. Łomińska-Płatek, Archives of Environmental Protection 44, 1, 69-75 (2018)

20. H. Ma, H.E. Allen, Y. Yin, Wat. Res. 35, 4, 985-996 (2001)

21. M. Grzegorczuk-Nowacka, Adsorption of fulvic acids from aqueous solutions (Politechnika Krakowska, Kraków, 2012)

22. M. Becher, D. Kalembasa, K. Pakuła, E. Malinowska, Agricultura 12, 4, 7-13 (2013)

23. P. Boguta, V. D’Orazio, Z. Sokołowska, N. Sensei, Journal of Geochemical Exploration 168, 119-126 (2016) 